\title{
Title: \\ Spatial distributions of aerosol loadings and depositions in East Asia during the year 2010
}

4

5

6

7

8

9

10

11

12

13

14

15

\section{Authors:}

Soon-Ung Park

Affiliation: Center for Atmospheric and Environmental Modeling

Address: Byuksan 1-cha Digital Valley Rm. 1011-2 Guro-dong, Guro-gu, Seoul 152-775, Korea

E-mail: supark@ snu.ac.kr

\section{Corresponding Author:}

Soon-Ung Park

Affiliation: Center for Atmospheric and Environmental Modeling

Address: Byuksan 1-cha Digital Valley Rm. 1011-2

Guro-dong, Guro-gu, Seoul 152-775, Korea

E-mail: $\underline{\text { supark@ @nu.ac.kr }}$

Tel: 82-2-885-6715; Fax: 82-2-886-6712

Atmospheric Environment

Revised on 12 February 2015 
1 Spatial distributions of aerosol loadings and depositions in East Asia during the

year 2010

Soon-Ung Park ${ }^{*}$

${ }^{*}$ Center for Atmospheric and Environmental Modeling, Seoul, Korea

\section{Abstract}

Aerosol Modeling System (AMS) that is consisted of the Asian Dust Aerosol Model2 (ADAM2) and the Community Multi-scale Air Quality (CMAQ) modeling system has been employed to document the geographical distributions of both the annual averaged Asian dust aerosol and the anthropogenic aerosols concentrations and their total depositions in the East Asia region for the year 2010. It is found that AMS simulates quite well the monitored $\mathrm{PM}_{10}$ concentration with a root mean square error (RMSE) of $9.2 \mu \mathrm{g} \mathrm{m}^{-3}$ and a normalized mean square error (NMSE) of $5.5 \%$ in South Korea and the RMSE of less than $33 \mu \mathrm{g} \mathrm{m}^{-3}$ with a NMSE of less than $7.8 \%$ at the monitoring sites in China. The annual mean surface (column integrated) aerosol concentrations in the East Asia region affect in a wide region as a complex mixture of the Asian dust (AD) aerosol and the anthropogenic aerosol (AA), more predominated by the $\mathrm{AD}$ aerosol in the Asian dust source region of northern China and Mongolia with the annual mean (column integrated) $\mathrm{PM}_{10}$ concentration of more than $200 \mu \mathrm{g} \mathrm{m}^{-3}\left(350 \mathrm{mg} \mathrm{m}^{-2}\right)$. Whereas AA is dominated in the high pollutant emission regions of southern and eastern China and northern India with the annual mean surface (column integrated) concentration of more than $110 \mu \mathrm{gm}^{-3}$ $\left(140 \mathrm{mg} \mathrm{m}^{-2}\right)$ in eastern China. On the other hand the mixed aerosols $(\mathrm{AD}+\mathrm{AA})$ are dominated in the downwind regions of the Yellow Sea, the East China Sea, the Korean peninsula, Japan, and the Northwest Pacific Ocean. It is also found that the annual total deposition of aerosols in the model domain is $4.9 \times 10^{8} \mathrm{t}\left(3.7 \times 10^{8} \mathrm{t}\right.$ by $\mathrm{AD}$ aerosol and $1.2 \times 10^{8} \mathrm{t}$ by AA), of which $66 \%\left(3.2 \times 10^{8} \mathrm{t}\right)$ is found to be contributed by the dry deposition $\left(3.1 \times 10^{8} \mathrm{t}\right.$ by AD aerosol and $1.3 \times 10^{7} \mathrm{t}$ by AA) and $34 \%$ $\left(1.7 \times 10^{8} \mathrm{t}\right)$ by the wet deposition $\left(1.0 \times 10^{8} \mathrm{t}\right.$ by $\mathrm{AA}$ and $6.6 \times 10^{7} \mathrm{t}$ by $\mathrm{AD}$ aerosol $)$, suggesting significant impacts of aerosols on environment and the terrestrial and marine eco-systems in East Asia. 
2 Keywords: Aerosol Modeling System (AMS), Aerosol deposition, Anthropogenic aerosol, Asian 3 Dust Aerosol Model2 (ADAM2), Column integrated aerosol concentration, Community Multi-scale Air Quality (CMAQ)

\section{Introduction}

Atmospheric aerosols can affect the quality of our lives significantly because of their potential impacts on human health and the environment. The sub-micrometer size of aerosols can be inhaled and thus may pose certain health hazards (Bates et al., 1966; Pope et al., 1992; Dockery et al., 1992; 1993; Binkowski and Shankar, 1995; Balásházy et al., 2003; Yadav et al. 2003; Davis et al., 2010), resulting in an increase in mortality (Perez et al., 2008; Jiménez et al., 2010; Sajani et al., 2010) and in respiratory (Cowie et al., 2010) and cardiovascular diseases(Chan et al., 2008; Middleton et al., 2008). Because aerosols also scatter light, they strongly influence the radiative budget of the Earthatmosphere system; they also reduce visibility and diminish the aesthetic scenery (IPCC, 1996; Jacobson, 2001; Lee and Sequerira, 2001; Kaufman et al., 2002; Watson, 2002; Crutzen 2004; Chang and Park, 2003; Penner et al., 2004; Park et al., 2005; Jung et al., 2009). Depositions of aerosols can affect significantly the terrestrial and marine eco-systems (Baker and Croot, 2010).

Asia is a major source of both natural aerosol (Asian dust) and anthropogenic aerosols over the Northern Hemisphere. Asian dust that is a typical example of mineral aerosol occurs in northern China and Mongolia more frequently during the spring season (Gao et al., 2000; Husar et al., 2001; In and Park, 2003; Park and In, 2003; Park and Lee, 2004; Yu et al., 2011) and has its increasing occurrence trend due to desertification in some of regions. Anthropogenic aerosols that are mainly originated from human activities and the formation by gas to aerosol conversion of pollutants have also an increasing trend due to the rapid economic expansion in many Asian countries (Chun and Lim, 2003' Lee et al., 2006; Kim et al., 2008; Park et al., 2012). Therefore the atmospheric aerosols in this region are the complex mixture of various aerosols including Asian dust and anthropogenic aerosols (Secondary 
1 inorganic aerosol, Secondary organic aerosol, Black carbon, Organic carbon, Water droplet and 2 emitted particulate matter) (Park et al., 2013).

Recently Park et al. (2012) have developed the Aerosol Modeling System (AMS) that is composed of the Asian Dust Aerosol Model2 (ADAM2) for the Asian dust aerosol modeling and the Community Multi-scale Air Quality (CMAQ) Version 4.7.1 model for the anthropogenic aerosol modeling to predict high aerosol concentration events in Asia. This model has been used to simulate dense haze events occurred in May 2010 (Park et al., 2013a) and in January 2013 (Park et al., 2013b) in East Asia

8 and found to simulate successfully these events.

Impact assessments of aerosols on the health, environment, eco-systems and climate variation require temporal and spatial distributions of aerosols with chemical compositions for a long term. However, long-term statistical data of aerosols are not usually available. The present study will provide a data set of aerosols for a year to make it possible to assess the effects of aerosols on health and environment.

The purpose of this study is to examine the spatial distributions of annual mean Asian dust and anthropogenic aerosols including Secondary Inorganic aerosol (SIA), Black Carbon (BC), Organic Carbon (OC), Secondary organic aerosol (SOA) and anthropogenic $\mathrm{PM}_{10}$ concentrations and column integrated concentrations and the annual total depositions of these aerosols simulated by the Aerosol Modeling System (AMS) in the East Asian domain for the year 2010.

\section{Model Descriptions}

\subsection{Meteorological model}

The meteorological model used in this study is the fifth generation meso-scale model of nonhydrostatic version (MM5; Pennsylvania State University / National Center for Atmospheric Research) defined in the $x, y$ and $\sigma$ coordinate (Grell et al., 1994; Dudhia et al., 1998). The model domain (Fig. 1) has the horizontal resolution of $27 \times 27 \mathrm{~km}^{2}$ with 30 vertical layers in the Asian region excluding Middle East (East Asia). 
The NCEP FNL re-analysis data on a $1.0 \times 1.0$ degree grid are used for the initial and lateral boundary conditions for the model.

\subsection{Aerosol Modeling System (AMS)}

The Aerosol Modeling System (AMS) is consisted of the Asian Dust Aerosol Model2 (ADAM2; Park et al., 2010) for the simulation of the Asian dust aerosol and the Community Multi-scale Air Quality (CMAQ) Version 4.7.1 modeling system (http://www.cmaq-model.org) for the estimation of anthropogenic aerosols with emission data of pollutants $\left(\mathrm{SO}_{2}, \mathrm{NO}_{\mathrm{x}}, \mathrm{VOC}, \mathrm{CO}, \mathrm{NH}_{3}, \mathrm{BC}, \mathrm{OC}\right.$ and $\left.\mathrm{PM}_{10}\right)$ in the model domain.

\subsubsection{ADAM2}

The ADAM2 model is an Eulerian dust transport model that includes the specification of the dust source regions delineated by the statistical analysis of the World Meteorological Organization (WMO) 3 hourly reporting dust data and statistically derived dust emission conditions in Sand, Gobi, Loess and Mixed surface soil in the model domain (Fig. 1). The model uses the suspended particle-size distribution parameterized by the several log-normal distributions in the source regions, based on the parent soil particle-size distributions with the used of the concept of the minimally and fully dispersed particle-size distribution (Lu and Shaw, 1999; Gomes et al., 1990; Shao et al., 2002; Park and Lee, 2004). It has 11-size of bins with near the same logarithm interval for particles of $0.15-35 \mu \mathrm{m}$ in radius (Park and In, 2003; Park and Lee, 2004). The model has a temporally varying emission reduction factors derived statistically using the normalized difference vegetation index (NDVI) in the different surface soil types in the Asian dust source region (Fig. 1). The detailed description of the model is given in Park et al. (2010a).

\subsubsection{CMAQ model}

The U.S. Environmental Protection Agency (EPA) Community Multi-scale Air Quality (CMAQ) 
Version 4.7.1 modeling system is a three-dimensional Eulerian atmospheric chemistry and transport modeling system that simulates airborne pollutants, ozone concentration, particulate matters, visibility, and acidic and nutrient pollutant species throughout the troposphere (University of North Carolina, 2010).

The aerosol component of the CMAQ Version 4.7.1 model has the particle size distribution as the superposition of three log-normal sub-distributions, called modes. Fine particles with diameters less than $2.5 \mu \mathrm{m}\left(\mathrm{PM}_{2.5}\right)$ are represented by two sub-distributions called the Aitken and accumulation modes. The Aitken mode includes particles with diameters up to approximately $0.1 \mu \mathrm{m}$ for the mass distribution and the accumulation mode covers the mass distribution in the range from 0.1 to $2.5 \mu \mathrm{m}$. The coarse mode covers the mass distribution in the range from 2.5 to $10 \mu \mathrm{m}$. The geometric standard deviations are $1.70 \mu \mathrm{m}, 2.00 \mu \mathrm{m}$ and $2.20 \mu \mathrm{m}$ for the Aitken, accumulation and coarse modes, respectively. The model includes the processes of coagulation, particle growth by the addition of mass and new particle formation (Binkowski and Roselle, 2003). The model domain of the CAMQ Version 4.7.1 is the same as that of the MM5 having the horizontal resolution of $27 \times 27 \mathrm{~km}^{2}$ with 30 vertical layers.

\subsubsection{Emission data}

Air pollutant emissions in Asia (Fig. 2) in the year 2006 are obtained from the Intercontinental Chemical Transport Experiment-Phase B (INTEX-B) that includes all major anthropogenic sources, excluding biomass burning (Zhang et al., 2009). More than $60 \%$ of the total Asian anthropogenic emissions are contributed by China. Pollutants emissions from biomass burning may have some impacts on aerosol loadings in South East Asia especially during the spring season. However the acceptable emission inventory data are not available at present.

Air pollutant emissions in South Korea in the year 2007 are obtained from the Clean Air Policy Supporting System (CAPSS, Korea Ministry of Environment) in a $3 \times 3 \mathrm{~km}^{2}$ grid scheme. These emission data are regridded in a $27 \times 27 \mathrm{~km}^{2}$ scheme for the simulation of aerosols in the model. The difference between the INTEX-B emission data and the regridded CAPSS data over South Korea is 
slight so that the impact of it is negligible.

\section{Results of the model simulation}

\subsection{Comparison of observed and simulated aerosol $\left(\mathbf{P M}_{10}\right)$ concentration}

The Aerosol Modeling System (AMS) has been employed to simulate concentrations of $\mathrm{PM}_{10}$ for the whole year of 2010 in the model domain in Fig. 1. Measured hourly $\mathrm{PM}_{10}$ concentrations at 28 monitoring sites over South Korea and four monitoring sites in China (Fig. 1) are used in the model evaluation for AMS.

Figure 3 shows the time series of the model simulated aerosol compositions of $\mathrm{PM}_{10}$ and the monitored $\mathrm{PM}_{10}$ concentrations at 6 monitoring sites over Korea (Fig. 1) for the period of 8-16 January 2010. The model simulated $\mathrm{PM}_{10}$ includes all kinds of aerosols such as secondary inorganic aerosol (SIA; $\mathrm{SO}_{4}^{2-}, \mathrm{NO}_{3}^{-}, \mathrm{NH}_{4}^{+}$), $\mathrm{BC}$ and $\mathrm{OC}$, Sea salt and secondary organic aerosol (OTHER), emitted unspecified $\mathrm{PM}_{10}$, Asian dust and water droplet (WATER). The model simulates quite well the total $\mathrm{PM}_{10}$ concentration compared with the observation (sum of all aerosol species except WATER). The high aerosol concentration occurred for the period from 12-14 January 2010 at all sites (Figs. 3a-f) is mixture of anthropogenic aerosols including SIA $\left(\mathrm{SO}_{4}{ }^{2-}, \mathrm{NO}_{3}{ }^{-}, \mathrm{NH}_{4}{ }^{+}\right), \mathrm{OC}, \mathrm{BC}$ and emitted $\mathrm{PM}_{10}$ with the natural aerosols such as Asian dust, Sea salt and water droplets. Among anthropogenic aerosols, the secondary inorganic aerosols (SIA) are predominated throughout the analysis period (Figs. 3a-f), suggesting the importance of pollutants emission of $\mathrm{SO}_{2}, \mathrm{NO}_{2}$ and $\mathrm{NH}_{3}$ that are precursors of SIA. It is worthwhile to note that the monitored aerosol concentration is not included water droplet so that the model simulated concentration without water droplet should be compared with the monitored aerosol concentration.

To examine the performance characteristics of AMS for simulating aerosol concentrations, the model simulated hourly mean $\mathrm{PM}_{10}$ concentrations at 28 monitoring sites over South Korea (Fig. 1) are compared with their corresponding monitored ones and then averaged to get area averaged $\mathrm{PM}_{10}$ concentration over South Korea. These data are used to get the monthly mean $\mathrm{PM}_{10}$ concentration and 
quantitative performance statistics for the near surface $\mathrm{PM}_{10}$ concentration for the whole year of 2010 .

Table 1 shows the quantitative performance statistics of AMS for the hourly measured-modeled $\mathrm{PM}_{10}$ concentrations averaged over South Korea using 28 monitoring sites (Fig. 1) for the whole year of 2010. The model simulates quite well the seasonal trend of the measured monthly mean $\mathrm{PM}_{10}$ concentration but slightly overestimates $\mathrm{PM}_{10}$ concentrations with a BIAS ranging $3.0 \mu \mathrm{g} \mathrm{m}^{-3}$ to 14.5 $\mu \mathrm{g} \mathrm{m}^{-3}$ and the mean normalize BIAS (MNB) ranging $7 \%$ to $36 \%$ during the winter and spring seasons while slightly underestimates them with a BIAS ranging $-0.6 \mu \mathrm{g} \mathrm{m}^{-3}$ (August) to $-8.0 \mu \mathrm{g} \mathrm{m}^{-3}$ (October) and the MNB ranging $-2 \%$ (November) to $-34 \%$ (July) during the summer season.

Therefore, the modeled annual mean $\mathrm{PM}_{10}$ concentration $\left(39.7 \mu \mathrm{g} \mathrm{m}^{-3}\right)$ is almost the same as that of observation $\left(39.3 \mu \mathrm{g} \mathrm{m}^{-3}\right)$ with an annual mean BIAS of $0.5 \mu \mathrm{g} \mathrm{m}^{-3}$ and an annual mean normalized BIAS (MNB) of $0.3 \%$. The root mean square error (RMSE) ranges $0.7 \mu \mathrm{g} \mathrm{m}^{-3}$ to $30.6 \mu \mathrm{g} \mathrm{m}^{-3}$ with annual mean of $9.2 \mu \mathrm{g} \mathrm{m}^{-3}$ and the normalized mean square error (NMSE) ranges $0.1 \%-40 \%$ with the annual mean of $5.5 \%$ in Korea, suggesting the usefulness of AMS for the simulation of $\mathrm{PM}_{10}$ concentrations.

The highest RMSE value in April (Table 1) is caused by the higher NDVI (Normalized Difference Vegetation Index) in 2010 than the 10-year averaged NDVI in the Asian dust source regions that uses in the model for the dust emission reduction factor. This may be caused the overestimation of the Asian dust concentration by the model for the dust events in April 2010.

The standard deviations of both the measured and modeled aerosol concentrations have the same seasonal trend with the maximum measured (modeled) value of $67.0 \mu \mathrm{g} \mathrm{m}^{-3}\left(66.4 \mu \mathrm{g} \mathrm{m}^{-3}\right)$ in March and the minimum measured (modeled) value of $17.2 \mu \mathrm{g} \mathrm{m}^{-3}\left(12.2 \mu \mathrm{g} \mathrm{m}^{-3}\right)$ in July. The model simulated annual mean standard deviation of the $\mathrm{PM}_{10}$ concentration $\left(35.6 \mu \mathrm{g} \mathrm{m}^{-3}\right)$ is slightly higher than that of observation $\left(31.2 \mu \mathrm{g} \mathrm{m}^{-3}\right)$. The relatively high standard deviations in March, November and December are caused by relatively high occurrence frequencies of the Asian dust events.

Asian dust events observed in South Korea were 12.3 days in 2010 that are higher than the annual mean event days of 9.6 days for the recent 10-year period (2000-2009). Of which $0.5,5.0,0.9,0.8$, 2.5 and 2.6 days were, respectively reported in January, March, April, May, November and December 
1 with the maximum $\mathrm{PM}_{10}$ concentration of $2,712 \mu \mathrm{g} \mathrm{m}^{-3} 20-21$ March and 1,664 $\mu \mathrm{g} \mathrm{m}^{-3}$ on 11-13

2 November 2010 at some monitoring sites in South Korea (KMA, 2010). A severe Asian dust event

3 occurred in March 2010 over East Asia was reported in Li et al. (2011).

Table 2 shows quantitative performance statistics of AMS for the near surface $\mathrm{PM}_{10}$ concentration at four monitoring sites in China (Fig. 1). The hourly measured-modeled $\mathrm{PM}_{10}$ concentrations at each site for the whole year of 2010 are used for the statistics. The annual mean BIAS (mean normalized BIAS) of the aerosol $\left(\mathrm{PM}_{10}\right)$ concentration ranges from $-21.1 \mu \mathrm{g} \mathrm{m}^{-3}(-20 \%)$ to $20.0 \mu \mathrm{g} \mathrm{m}^{-3}(20.7 \%)$. The RMSE ranges from $11.3 \mu \mathrm{g} \mathrm{m}^{-3}$ (NMSE of $0.5 \%$ ) to $33.4 \mu \mathrm{g} \mathrm{m}^{-3}$ (NMSE of $5.1 \%$ ) at the monitoring sites in China.

Tables 1 and 2 clearly indicate that the model results can be used to examine the spatial distribution of the annual mean aerosol concentration and other related quantities such as depositions that are closely related with the monitored $\mathrm{PM}_{10}$ concentration.

\subsection{Spatial distributions of annual mean $\mathbf{P M}_{10}$ concentrations}

To minimizing the impact of no boundary fluxes along the boundary of the model domain at the initial time, the model has been performed for one day period with the emission data in Fig. 2 to get the initial concentration data in the model domain that is expended 2 more grids outward from the model boundary. The boundary concentrations are obtained with a positive-definite zero-flux outflow boundary condition (In and Park 2002).

Figure 4 shows the model simulated surface mean aerosol concentration $\left(\mathrm{PM}_{10}\right)$ averaged for the whole year of 2010. The Asian dust aerosol ( $\mathrm{PM}_{10}$ ) (Fig. 4a) originated in the Asian dust source region (Fig. 1) affects far downwind regions of the Northwestern Pacific Ocean. The annual mean Asian dust aerosol $\left(\mathrm{PM}_{10}\right)$ concentration exceeding $10 \mu \mathrm{g} \mathrm{m}^{-3}$ covers over eastern China, the north of the Tibetan Plateau, most parts of Mongolia, Korea peninsula, the Yellow Sea and the East China Sea with a maximum concentration of more than $300 \mu \mathrm{g} \mathrm{m}^{-3}$ at the northeastern Taklimakan desert. On the other hand the annual mean surface anthropogenic aerosol concentrations (Fig 4b) including SIA, OC, BC SOA and emitted $\mathrm{PM}_{10}$ that are originated from pollutants emissions affect all over the Asian region 
except for the south of Philippines, over the Tibetan Plateau, the southern parts of Russia and eastern Central Asia. The annual mean anthropogenic aerosol concentration exceeding $10 \mu \mathrm{g} \mathrm{m}^{-3}$ covers all over the eastern and southern parts of China, Korean peninsula and northern India where pollutants emissions are large (Fig. 2), with a maximum concentration exceeding $110 \mu \mathrm{g} \mathrm{m}^{-3}$ near Beijing.

Therefore, the annual mean surface total aerosol concentration (Asian dust + anthropogenic aerosol) affects all East Asia regions (Fig. 4c). The annual mean high surface aerosol concentration exceeding $50 \mu \mathrm{g} \mathrm{m}^{-3}$ extends eastward from the Taklimakan desert region to northeast China with the maximum concentration of more than $304 \mu \mathrm{g} \mathrm{m}^{-3}$ at the eastern part of the Taklimakan desert area. This is mainly contributed by the Asian dust aerosol (Fig. 4a). Another annual mean high aerosol concentrations exceeding $50 \mu \mathrm{g} \mathrm{m}^{-3}$ occur in the most parts of eastern China and northern India in the high pollutant emission region (Fig 2) with a maximum concentration of more than $160 \mu \mathrm{g} \mathrm{m}^{-3}$ near Beijing. These are mainly contributed by anthropogenic aerosols.

Figure 5 shows spatial distributions of the annual mean column integrated Asian dust $\left(\mathrm{PM}_{10}\right)$ aerosol concentration (Fig. 5a), anthropogenic aerosol concentration (Fig 5b) and the total concentration (Fig. 5c). The spatial distribution pattern of the annual mean column integrated Asian dust aerosol concentration is quite similar to that of the annual mean surface Asian dust concentration (Fig 4a) but spreads more wider regions over the Northwest Pacific Ocean. The annual mean atmospheric loading of the Asian dust (Fig. 5a) exceeding $100 \mathrm{mg} \mathrm{m}^{-2}$ extends east-southeastwards from the Taklimakan desert region to the East Sea of Korea with the maximum concentration of 360 $\mathrm{mg} \mathrm{m}^{-2}$ in the Tengger desert in China. Whereas the annual mean column integrated anthropogenic aerosols concentration (Fig 5b) exceeding $30 \mathrm{mg} \mathrm{m}^{-2}$ covers northern India, the most parts of China to the east of the Tibetan Plateau and the Korean peninsula with the maximum concentration of more than $140 \mathrm{mg} \mathrm{m}^{-2}$ in the Sichuan province.

The annual mean column integrated total aerosol (Asian dust + anthropogenic aerosol) concentration (Fig. 5c) exceeding $10 \mathrm{mg} \mathrm{m}^{-2}$ extends from $10 \mathrm{~N}$ to $60 \mathrm{~N}$ in the model domain. More than $280 \mathrm{mg} \mathrm{m}^{-2}$ of atmospheric aerosol loading extends eastward from the Taklimakan desert region to the Yellow Sea with the maximum concentration of about $480 \mathrm{mg} \mathrm{m}^{-2}$ in the Henan province where 
both the Asian dust aerosol (Fig. 5a) and the anthropogenic aerosols (Fig. 5b) are contributed to this maximum concentration.

\subsection{Spatial distributions of annual total depositions of Asian dust and anthropogenic aerosols}

The model simulated annual total depositions of the Asian dust aerosol and the anthropogenic aerosols (SIA, SOA, BC, OC, anthropogenic $\mathrm{PM}_{10}$ and Sea salt) for 2010 are respectively shown in Figs. 6 and 7.

Figure 6 shows the spatial distributions of annual total depositions of the Asian dust aerosol for 2010. The spatial distribution of the annual total aerosol depositions (dry + wet) (Fig. 6a) just follows that of the annual mean surface Asian dust concentration (Fig. 4a). The zone of the maximum deposition extends downwind ward from the Asian dust source region (Fig. 1) to the northwest Pacific Ocean with the maximum annual total deposition of more than $703 \mathrm{t} \mathrm{km}^{-2}$ at the northeastern Taklimakan desert. The total deposition of Asian dust aerosol over the Asian dust source region and the land region is mainly contributed by the dry deposition process (Fig. 6b) whereas over the ocean the wet deposition (Fig. 6c) is largely contributed to the total deposition. The annual total deposition of Asian dust aerosol originated from the Asian dust source region exceeds $10 \mathrm{t} \mathrm{km}^{-2}$ over the northwestern Pacific Ocean that may affect marine ecology in this region. The annual total dust deposition in the model domain is about $3.7 \times 10^{8} \mathrm{t}$, of which about $82 \%\left(3.1 \times 10^{8} \mathrm{t}\right)$ is contributed by dry deposition mainly in the Asian dust source region while $18 \%\left(6.7 \times 10^{7} \mathrm{t}\right)$ is contributed by wet deposition in the downwind region of oceans. This annual total deposition of the Asian dust aerosol $\left(3.7 \times 10^{8} \mathrm{t}\right)$ is the same order of magnitude of that estimated by IPCC $\left(2.4 \times 10^{8} \mathrm{t}\right)$. Park et al. $(2010 \mathrm{~b})$ estimated that of $8.2 \times 10^{8} \mathrm{t} \mathrm{yr}^{-1}$ in 2007 . This difference is largely associated with the year by year dust occurrence frequencies in the Asian region.

Figure 7 shows the spatial distribution of the annual total anthropogenic aerosol deposition. The spatial distribution pattern of the total deposition (wet + dry) of the anthropogenic aerosol (Fig. 7a) is 
quite similar to that of the annual mean concentration of the anthropogenic aerosols (Fig. 4b) with the maximum deposition of $45.0 \mathrm{t} \mathrm{km}^{-2}$ in the Sichuan province. Most of the annual total deposition of the anthropogenic aerosol is mainly contributed by the wet deposition (Fig. 7c) rather than the dry deposition (Fig. 7b). The dry deposition of the anthropogenic aerosol is one order magnitude smaller than that of the wet deposition. The annual total deposition of the anthropogenic aerosol in the whole model domain is about $1.1 \times 10^{8} \mathrm{t}$, which is one-third of the Asian dust aerosol, of which $88 \%(1.0 \times$ $10^{8} \mathrm{t}$ ) is contributed by wet deposition mainly in the high pollutants emission region (Figs. 2 and 7c) and the rest of $12 \%\left(1.3 \times 10^{7} \mathrm{t}\right)$ is contributed by the dry deposition (Fig. $7 \mathrm{~b}$ ).

To assess the performance of the AMS model for the wet deposition of the secondary inorganic aerosols (SIA; sulfate, nitrate and ammonium), two sites in South Korea (Gosan and Ganghwa) and three sites in Japan (Rishiri, Sado-Seki and Oki) that belong to the EANET (http://www.eanet.asia/product/index.html) are taken to compare the model results with the monitored data. Table 3 shows that the wet deposition of SIA simulated by the model is the same order of magnitude of the observed one at all sites, suggesting the potential usefulness of the AMS model for the simulation of wet deposition of SIA.

\subsection{Spatial distributions of annual total aerosol (Asian dust + anthropogenic aerosols)} deposition in Asia

Figure 8 shows annual total aerosol deposition (anthropogenic + Asian dust aerosol) of all kinds of aerosols in the East Asia domain. High aerosol deposition exceeding $300 \mathrm{t} \mathrm{km}^{-2} \mathrm{yr}^{-1}$ (Fig. 8a) occurs in northern China and Mongolia mainly due to the Asian dust. The annual total aerosol deposition in the whole model domain is $4.9 \times 10^{8} \mathrm{t}$, of which $77 \%\left(3.7 \times 10^{8} \mathrm{t}\right)$ is contributed by the Asian dust aerosol and $23 \%\left(1.2 \times 10^{8} \mathrm{t}\right)$ is contributed by the anthropogenic aerosols. This total deposition is largely contributed by dry deposition of $3.2 \times 10^{8} \mathrm{t}(66 \% ; 3 \%$ by the anthropogenic aerosols and $63 \%$ by the Asian dust aerosol) in the Asian dust source region (Fig. 8b).

It is quite clear that the dry deposition process is more effective for the Asian dust aerosol to 
remove the aerosol from the atmosphere while the wet deposition process is more effective for the anthropogenic aerosol. This may be attributed to the difference of the particle-size distributions between the Asian dust aerosol and the anthropogenic aerosols. The former is relatively larger than the latter. However, high aerosol deposition over southern and eastern China, over the Yellow Sea, the East Sea of Korea, the South China Sea and the eastern part of Japan are largely contributed by anthropogenic aerosols that are mainly contributed by the wet deposition (Fig. 8c).

\section{Conclusions}

Aerosol Modeling System (AMS) that is consisted of the Asian Dust Aerosol model2 (ADAM2) for the Asian dust aerosol modeling and the Community Multi-scale Air Quality (CMAQ) Version 4.7.1 modeling system for the anthropogenic aerosol modeling has been employed to document spatial distributions of the Asian dust aerosol and the anthropogenic aerosols for the year of 2010 in the East Asia domain. The spatial distributions of annual mean surface concentrations, column integrated concentrations, annual total dry and wet depositions of both the Asian dust aerosol and the anthropogenic aerosols have been documented for the first time in the whole East Asia domain.

AMS is found to simulate quite reasonably the monitored aerosol concentrations with a BIAS of 0.5 $\mu \mathrm{g} \mathrm{m}^{-3}$ and a mean normalized BIAS of $0.3 \%$ in Korea and the absolute BIAS less than $21.1 \mu \mathrm{g} \mathrm{m}^{-3}$ and the mean normalized BIAS less than $20.7 \%$ over China. The root mean square error is found to be $9.2 \mu \mathrm{g} \mathrm{m}^{-3}$ with a normalized mean square error of $5.5 \%$ in Korea and that is less than $33.4 \mu \mathrm{g} \mathrm{m}^{-3}$ with the normalized mean square error of less than $7.5 \%$ over China.

It is found that the annual mean surface concentration of the Asian dust aerosol exceeding $10 \mu \mathrm{g} \mathrm{m}^{-}$ ${ }^{3}$ extends east-south eastward from northwestern China in the East Asia dust source region of the Takhlimakan desert to the East China Sea covering the whole Asian dust source region, eastern China, the Yellow Sea and the Korean peninsula with maximum concentration of more than $300 \mu \mathrm{g} \mathrm{m}^{-3}$ at the northeastern part of the Takhlimakan desert. Whereas that of the anthropogenic aerosol exceeding 10 $\mu \mathrm{g} \mathrm{m}^{-3}$ covers over the eastern and southern parts of China, northern India and the Korean peninsula with the maximum concentration of $110 \mu \mathrm{g} \mathrm{m}^{-3}$ over the Shandong province where the pollutants 
emissions are high.

Consequently the annual mean surface total aerosol (Asian dust + anthropogenic aerosol) concentration exceeding $10 \mu \mathrm{g} \mathrm{m}^{-3}$ extends further downwind region from northwestern China where the annual mean Asian dust aerosol concentration exceeds $300 \mu \mathrm{g} \mathrm{m}^{-3}$ and eastern China where the annual mean anthropogenic aerosol concentration exceeds $150 \mu \mathrm{g} \mathrm{m}^{-3}$ to the Northwest Pacific Ocean. Another annual mean high aerosol concentration occurs in northern India and over the Bay of Bengal caused by the anthropogenic aerosol.

The spatial distribution of the column integrated annual mean Asian dust aerosol concentration is found to indicate clearly that the Asian dust aerosol affects not only in the Asian dust source region with the annual mean atmospheric dust loading of more than $350 \mathrm{mg} \mathrm{m}^{-2}$ but in the downwind regions of the Northwest Pacific Ocean with that of more than $50 \mathrm{mg} \mathrm{m}^{-2}$. Whereas the high annual mean column integrated anthropogenic aerosol is found to occur not only in the high pollutant emission regions of northern India and eastern China but in the far downwind regions of the Bay of Bengal and the Northwest Pacific Ocean. This high atmospheric loading of the anthropogenic aerosol together with the high Asian dust aerosol loading over China, Mongolia, the Korean peninsula and the Northwest Pacific Ocean may affect significantly the radiative budget of the Earth-atmosphere system in this region.

It is found that the annual total deposition of the Asian dust aerosol in the model domain is about $3.7 \times 10^{8} \mathrm{t}$, of which $82 \%\left(3.1 \times 10^{8} \mathrm{t}\right)$ is contributed by the dry deposition mainly in the Asian dust source region and $18 \%\left(6.7 \times 10^{7} \mathrm{t}\right)$ is contributed by the wet deposition mainly over oceans, whereas the annual total deposition of the anthropogenic aerosol in the whole model domain is $1.1 \times 10^{8} \mathrm{t}$, of which $88 \%\left(1.0 \times 10^{8} \mathrm{t}\right)$ is contributed by the wet deposition largely over the high pollutant emission regions. Consequently, the annual total aerosol deposition in the model domain is found to be $4.9 \times 10^{8}$ $\mathrm{t}\left(3.7 \times 10^{8} \mathrm{t}\right.$ by Asian dust aerosol and $1.2 \times 10^{8} \mathrm{t}$ by Anthropogenic aerosol), of which $3.2 \times 10^{8} \mathrm{t}$ $(66 \%)$ is found to be contributed by the dry deposition $\left(3.1 \times 10^{8}\right.$ t by Asian dust aerosol and $1.3 \times 10^{7}$ $\mathrm{t}$ by anthropogenic aerosol) and $1.7 \times 10^{8} \mathrm{t}(34 \%)$ by the wet deposition $\left(1.0 \times 10^{8} \mathrm{t}\right.$ by anthropogenic aerosol and $6.6 \times 10^{7}$ t by Asian dust aerosol). This suggests that the total aerosol deposition (Asian 
dust aerosol and anthropogenic aerosol) can affect significantly both the terrestrial and marine ecosystems in the Asian region.

Above estimated annual mean aerosol concentrations and the annual total depositions could have some errors caused by meteorological fields, emission inventory data, CMAQ and ADAM2 models that are used in this study. The monitored $\mathrm{PM}_{10}$ concentrations for a year long period in South Korea and several sites in China allow to estimate the NMSE of less than $8 \%$. However, the error analysis of the annual total aerosol deposition can not be made due to the lack of monitored data for a year long period. To estimate more accurate amounts of aerosol loading and depositions is required to employ both the model and observation data from many monitoring sites in the model domain via data assimilation or the inverse model even if it is future work.

This study mainly pertains to the documentation of the spatial distributions of concentrations and depositions of the Asian dust aerosol and the anthropogenic aerosols in the East Asia domain for the year 2010. However, year by year dust occurrence frequencies and the pollutant emission rates in this region are changing. To get more meaningful statistical results for the use of the impact assessment of these aerosols on environment and eco-systems in Asia, model simulations for several years are required. This is now on hand.

\section{Acknowledgements}

This work was funded by the Korea Meteorological Administration Research and Development Program under Grant CATER 2012-7010. Comments of two anonymous reviewers are appreciated.

\section{References}

Baker, A.R., Croot, P.L., 2010. Atmospheric and marine controls on aerosol iron solubility in seawater, Marine Chemistry, 120, 4-13.

Balásházy, I., Hofmann, W., Heistracher, T., 2003. Local particle deposition pattern may play a key role in the development of lung cancer, J. Appl. Physiol., vol. 94, pp. 1719-1725. 
Bates, D.V., Fish, B.R., Hatch, T.F., Mercer, T.T., Morrow, P.E., 1966. Deposition and retention models for internal dosimetry of the human respiratory trac, Health Phys., vol. 12, pp. 173-207.

Binkowski, F.S., Shankar, U.,1995. The regional particulate matter model, 1.Model description and preliminary results, J. Geophys. Res., vol. 100(D12), pp. 26191-26209.

Binkowski, F.S., Roselle, S.J., 2003. Model-3 Community Multiscale Air Quality (CMAQ) model aerosol component 1. Model description, J. Geophys. Res., vol. 108(D6), p. 4183.

Chang, L.-S., Park, S.-U., 2004. Direct radiative forcing due to anthropogenic aerosols in East Asia during April 2001, Atmos. Envoron., vol. 38, pp. 4467-4482.

Chan, C.C., Chuang, K.J., Chen, W.J., Chang, W.T., Lee, C.T., Peng, C.M., 2008. Increasing cardiopulmonary emergency visits by long-range transported Asian dust storms in Taiwan, Environ Res 106(3):393-400.

Chun, Y., Lim, J.Y., 2004. The recent characteristics of Asian dust and haze event in Seoul, Korea, Meteorol. Atmos. Phys. 2004: 87: 143-152.

Crutzen, P., 2004. New directions: the growing urban heat and pollution island effect - impact on chemistry and climate, Atmos. Environ., vol. 38, pp. 3539-3540.

Cowie, G., Lawson, W., Kim, N., 2010. Australian dust causing respiratory disease admissions in some North Island, New Zealand Hospitals, New Zeal. Med. J., vol. 123(1311), p. 87.

Davis, M.E., Laden, F., Hart, J.E., Gashick, E., Smith, T.J., 2010. Economic activity and trends in ambient air pollution. Environ. Health Persp. 118: 614-619.

Dockery, D.W., Schwartz, J., Spengler, J.D., 1992. Air Pollution and Daily Mortality: Associations with Particulates and Acid Aerosols, Environ. Res., vol. 59, pp. 362-373.

Dudhia, J., Grill, D., Guo, Y.R., Hausen, D., Manning, K., Wang, W., 1998. PSU/NCAR mesoscale modelling system tutorial class notes (MM5 modelling system version 2)

Gao, Q.X., Li, L.J., Zhang, Y.G., Hu, M., 2000. Studies on the springtime dust storm of China. China Environmental Science 20 (6): 495-500.

Gomes, L., Bergametti, G., Dulac, F., Ezat, U., 1990. Assessing the actual size distribution of atmospheric aerosols collected with a cascade impactor, Journal of Aerosol Science 21, 47-59. 
Grell, G.A., Dudhia, J., Stauffer, D.R., 1994. A description of 5th generation Penn State/NCAR mesoscale model (MM5), NCAR TECH., Note NCAR/TN-398.

Husar, R. B., Tratt, D.M., Schichtel, B.A., Falke, S.R., Li, F., Jaffe, D., Gassó, S., Gill, T., Laulainen, N.S., Lu, F., Reheis, M.C., Chun, Y., Westphal, D., Holben, B.N., Gueymard, C., McKendry, I., Kuring,N., Feldman, G.C., McClain, C., Frouin, R.J., Merrill, J., DuBois, D., Vignola, F., Murayama, T., Nickovic, S., Wilson, W.E., Sassen, K., Sugimoto, N., Malm, W.C., 1998. Asian dust events of April 1998, Journal of Geophysical Research, vol. 106(D16), pp 18317-18330.

IPCC (Intergovernmental Panel on Climate Change), 1996. Climate Change 1995, The science of Climate change, Cambridge University Press, 573 pp.

IPCC (Intergovernmental Panel on Climate Change), Climate Change 2007: the physical science basis. Cambridge University Press; 2007. Cambridge UK and New York.

In, H-J., Park, S-U., 2002. A simulation of long-range transport of Yellow Sand observed in April 1998 in Korea, Atmos. Environ. 36: 4173-4187.

In, H-J., Park, S-U., 2003. The soil particle size dependent emission parameterization for an Asian dust (Yellow Sand) observed in Korea on April 2002, Atmos. Environ. 37: 4625-2636.

Jacobson, M.Z., 2001. Strong radiative heating due to the mixing state of black carbon in atmospheric aerosols, Nature, vol. 409(6821), pp 695-697.

Jung, J., Lee, H., Kim, Y.J., Liu, X., Zhang, Y., Gu, J., Fan, S., 2009. Aerosol chemistry and the effect of aerosol water content on visibility impairment and radiative forcing in Guangzhou during the 2006 Pearl River Delta campaign. J. Environ. Manage. 90: 3231-3244.

Kaufman, Y.J., Martins, J.V., Remer, L.A., Schoeberl, M.R., Yamasoe, M.A., 2002. Satellite retrieval of aerosol absorption over the oceans using sunglint, GEOPHYSICAL RESEARCH LETTERS, VOL. 29, NO. 19, 1928, doi:10.1029/2002GL015403.

Kim, K.W., Kim, Y.J., Bang, S.Y., 2008. Summer time haze characteristics of the urban atmosphere of Gwangju and the rural atmosphere of Anmyon, Korea. Environ. Monit. Assess. 141: 189-199.

Lee, Y.L., Sequeira, R., 2001. Visibility degradation across Hong Kong: its components and their relative contributions, Atmos. Environ., 34, pp 561-5872. 
Lee, K.H., Kim, Y.J., Kim, M.J., 2006. Characteristics of aerosol observed during two severe haze events over Korea in June and October 2004, Atmos. Environ., vol. 40, pp. 5146-5155.

Li, J., Han, Z., Zhang, R., 2011. Model study of atmospheric particulates during dust storm period in March 2010 over East Asia, Atmos. Environ. 45: 3954-3964.

Lu, H., Shao, Y., 1999. A new model for dust emission by saltation bombardment. Journal of Geophysical Research, 104, 16827-16842.

Middleton, N., Yiallouros, P., Kleanthous, S., Kolokotroni, O., Schwartz, J., Dockery, D.W., 2008. A 10-year time-series analysis of respiratory and cardiovascular morbidity in Nicosia, Cyprus: the effect of short-term changes in air pollution and dust storms. Environ Health 7:39; doi:10.1186/1476-069X-7-39 [Online 22 July 2008].

Park S.-U., In H.-J., 2003. Parameterization of dust emission for the simulation of the yellow sand (Asian dust) observed in March 2002 in Korea. J. Geophys. Res.. vol. 108(D19), pp 4618.

Park S.-U., Lee E.-H., 2004. Parameterization of Asian dust (Hwangsa) particle-size distributions for use in dust emission model. Atmos. Environ., vol. 38, pp. 2155-2162.

Park, S-U., Chang, L-S, Lee E-H., 2005. Direct radiative forcing due to aerosols in East Asia during a Hwangsa (Asian dust) event observed in 18-23 March 202 in Korea. Atmos. Environ. 39: 25932606.

Park, S.-U., Choe, A., Lee, E.-H., Park, M.-S., Song, X., 2010a. The Asian dust aerosol model 2 (ADAM2) with the use of normalized difference vegetation data (NDVI) obtained from the spot4/vegetation data, Theor. Appl. Climatol., vol. 101, pp. 191-208.

Park, S.-U., Choe, A., Park, M.-S., 2010b. Estimates of Asian dust deposition over the Asian region by using ADAM2 in 2007. Science of the Total Environment 408, 2347-2356.

Park, S.-U., Cho, J.H., Park, M.-S., 2012. A simulation of Aerosols in Asia with the use of ADAM2 and CMAQ, Advances in Fluid Mechanics and Heat \& Mass Transfer, pp. 258-263.

Park, S.-U., "The aerosol modeling system for the simulations of high aerosol concentration events in East Asia," Recent Advances in Environmental Science, P3 (plenary lecture in WSEAS),

Park, S.-U., Cho, J.H., Park, M.-S., 2013a. Identification of visibility reducing weather phenomena 
due to aerosols, Environmental Management and Sustainable Development, vol. 2, pp. 126-142.

Park, S.-U., Cho, J.H., Park, M.-S., 2013b. A simulation of haze and mist events observed in east Asia during 19-22 May 2010 using the Aerosol Modeling System (AMS), Recent Advances in Environmental Science, pp. 204-210, (WSEAS).

Penner, J.E.P., Dong, X., Chen, Y., 2004. Observational evidence of change in radiative forcing due to the indirect aerosol effect, Nature, vol. 427(6971), pp. 231-234.

Perez, L., Tobias, A., Querol, X., Künzli, N., Pey, J., Alastuey, A., 2008. Coarse particles from Saharan dust and daily mortality. Epidemiology 19:800-807.

Pope, C.A., Dockery, D.W., Xu, X., Spengler, J.D., Ware, J.H., Fay, M.E., Ferris, B.G., Speizer, F.E., 1993. An association between air pollution and mortality in six U.S. cities, New Engl. J. Med., vol. 329, pp. 1753-1759.

Sajani, Z.S., Miglio, R., Bonasoni, P., Cristofanelli, P., Marinoni, A., Sartini, C., 2010. Saharan dust and daily mortality in Emilia-Romagna (Italy). Occup Environ Med 68:446-451.

Shao, Y., Jung, E., Leslie, L.M., 2002. Numerical prediction of northeast Asian dust storms using an integrated wind erosion modeling system, Journal of Geophysic, 107 (D24), 4814 (doi:10.1029/2001JD001493).

University of North Carolina, Operational Guidance for the Community Multiscale Air Quality (CMAQ) Modeling System, Community Modeling and Analysis System Institute for the Environment, 2010.

Watson, J.G., 2002. Visibility: Science and regulation, J. Air Waste Ma., vol. 52, pp. 628-713.

Yadav, A.K., Kumar, K., Kasim, A., Sing, M.P., Parida, S.K., Sharan, M., 2003. Visibility and incidence of respiratory diseases during the 1998 haze episode in Brunei Darussala. J.Air Waste Ma. 53: 946-956.

Yu X., Zhu B., Yin Y., Yang J., Li Y., Bu X., 2011. A comparative analysis of aerosol properties in dust and haze-fog days in a Chinese urban region, Atmos. Res., vol. 99, pp. 241-247.

Zhang, Q., Streets, D. G., Carmichael, G. R., He, K. B., Huo, H., Kannari, A., Klimont, Z., Park, I. S., Reddy, S., Fu, J. S., Chen, D., Duan, L., Lei, Y., Wang, L. T., Yao, Z. L., 2009. Asian emissions in 
12006 for the NASA INTEX-B mission, Atmospheric Chemistry and Physics 9, 5131-5153.

2

3

4

5

6

7

8

9

10

11

12

13

14

15

16

17

18

19

20

21

22

23

24

25

26

27 


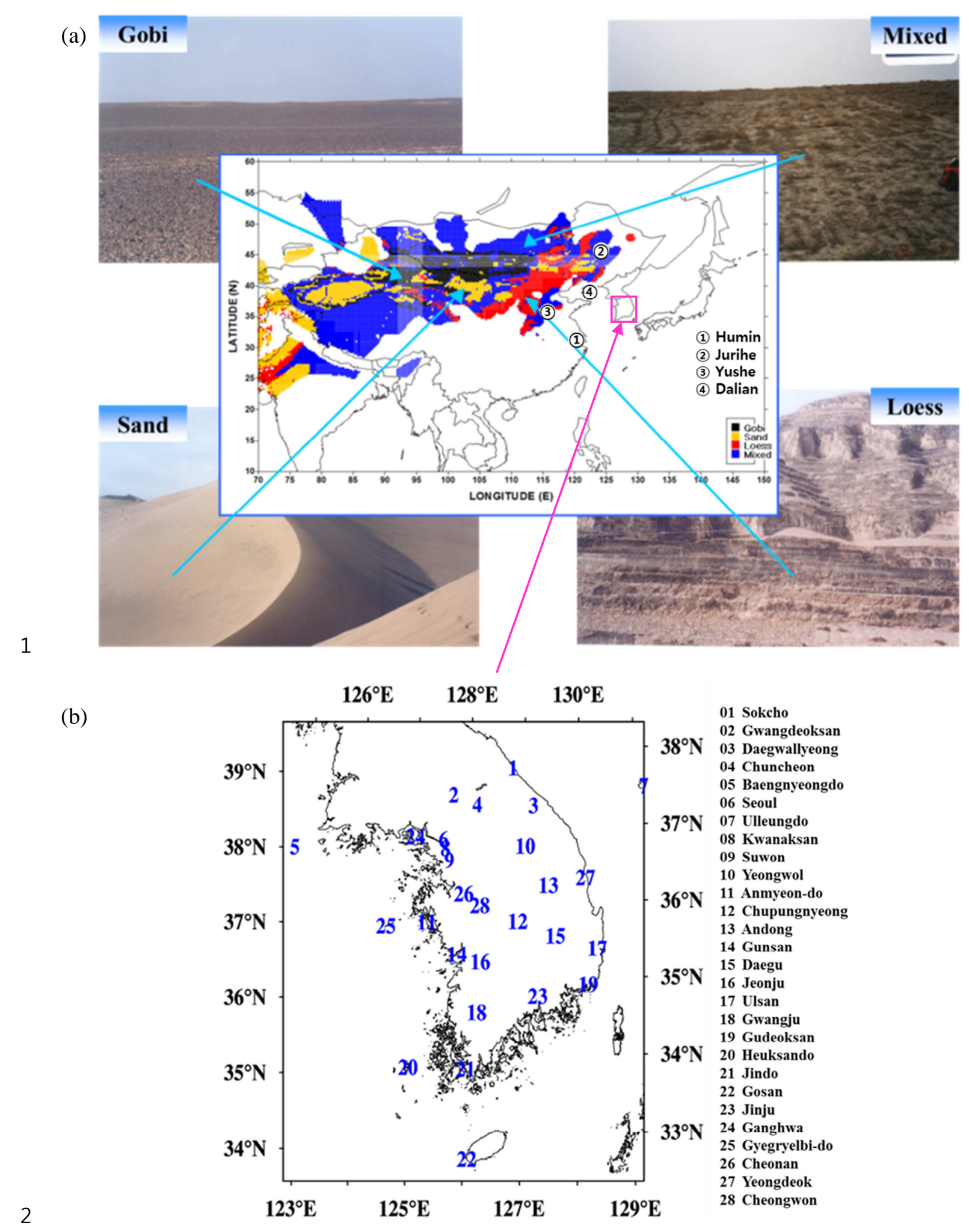

3 Fig. 1. (a) The model domain and the geographical distribution of the surface soil types (Black, Gobi;

4 Yellow, Sand; Red, Loess; Blue, Mixed) in the Asian dust source region, (b) Enlarged South Korea

5 map with the indication of $28 \mathrm{PM}_{10}$ monitoring sites. 
(a) $\mathrm{SO}_{2}$

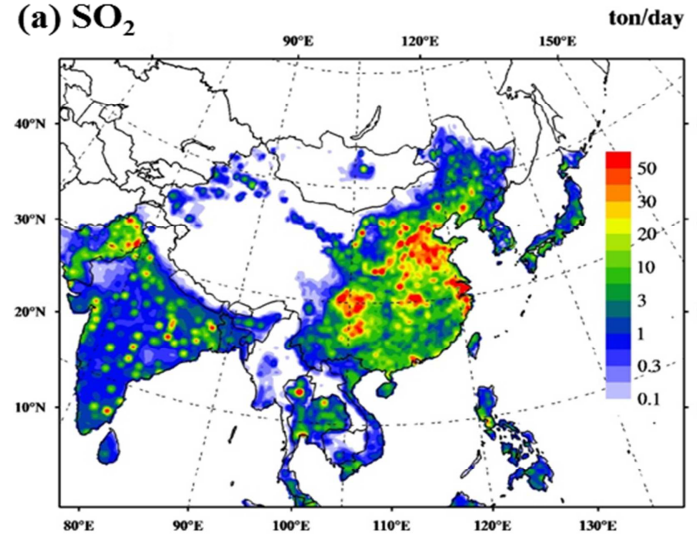

(c) $\mathrm{NH}_{3}$

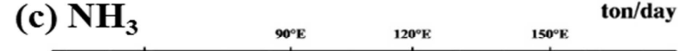

(b) $\mathrm{NO}_{\mathbf{x}}$

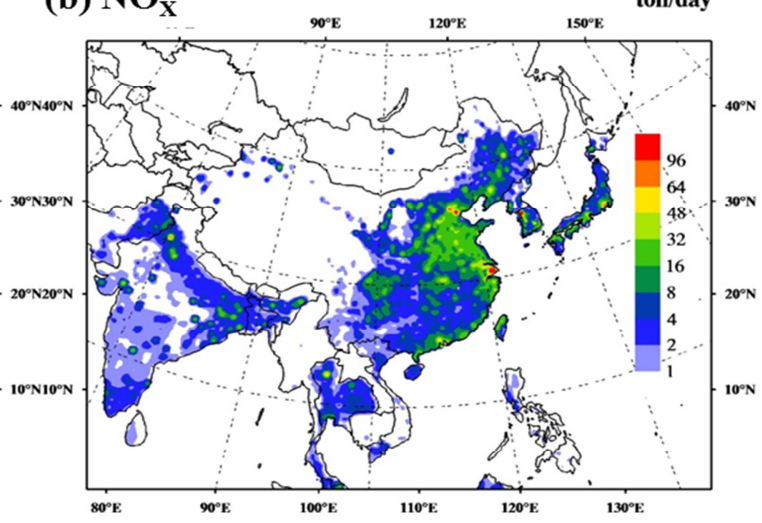

(d) $\mathbf{P M}_{10}$

ton/day
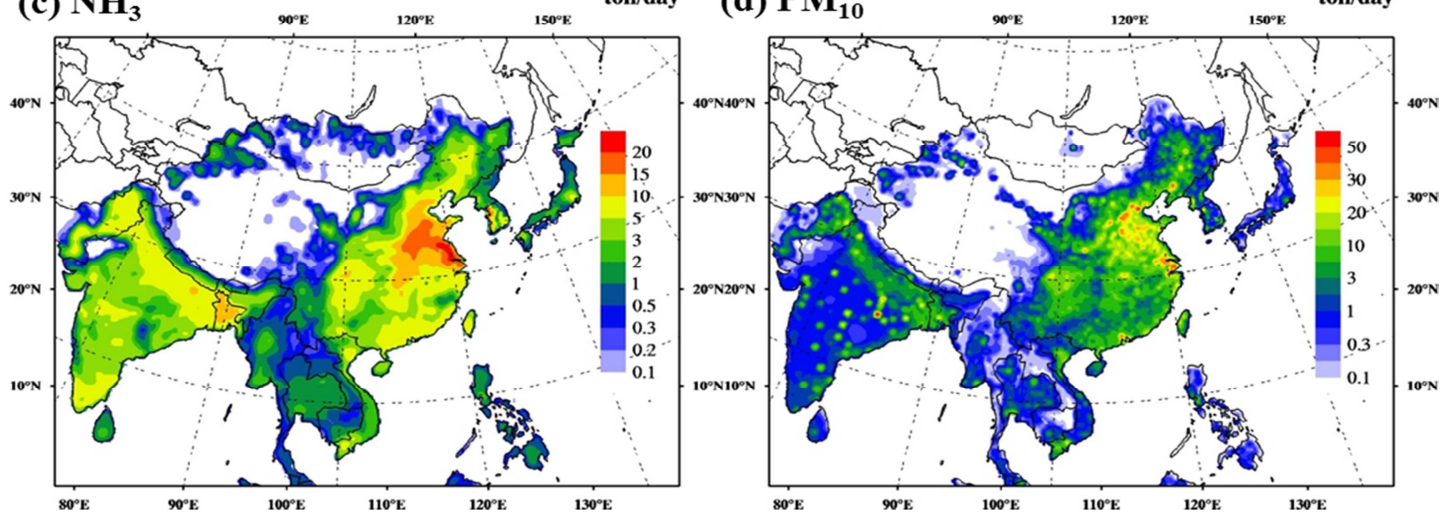

Fig. 2. Spatial distributions of emission rate $\left(\mathrm{t} \mathrm{day}^{-1}\right.$ grid $^{-1}$ ) of (a) $\mathrm{SO}_{2}$, (B) $\mathrm{NO}_{\mathrm{x}}$, (c) $\mathrm{NH}_{3}$ and (d) $\mathrm{PM}_{10}$ on May 2006 in the Asian domain (1 grid: $\left.27 \times 27 \mathrm{~km}^{2}\right)$. 
(a) Baengnyeongdo

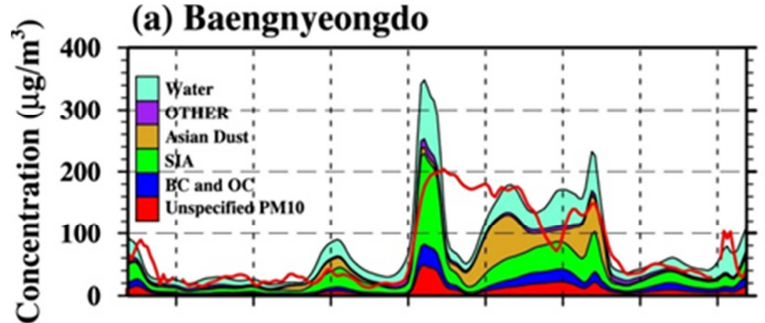

(b) Heuksando

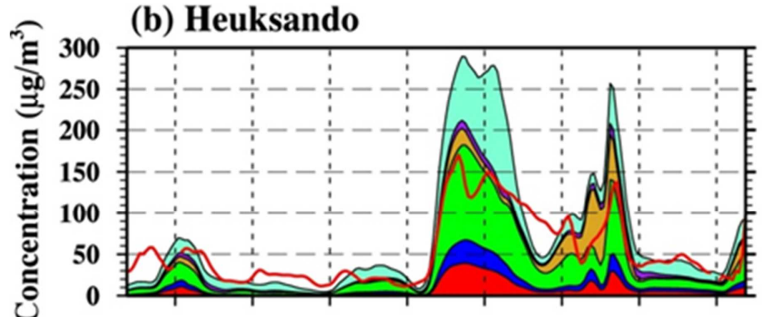

(c) Gosan

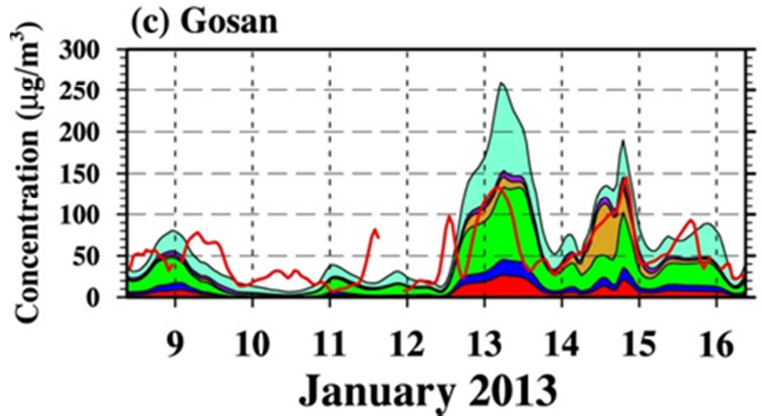

(d) Seoul

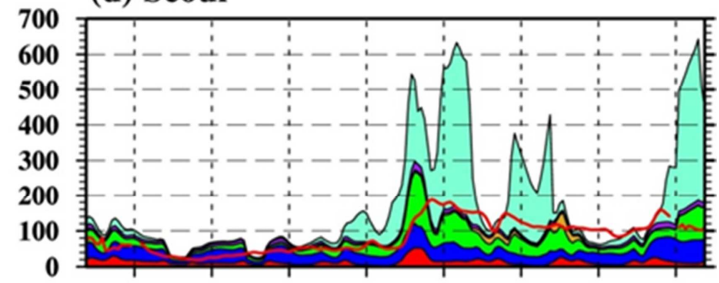

(e) Gunsan

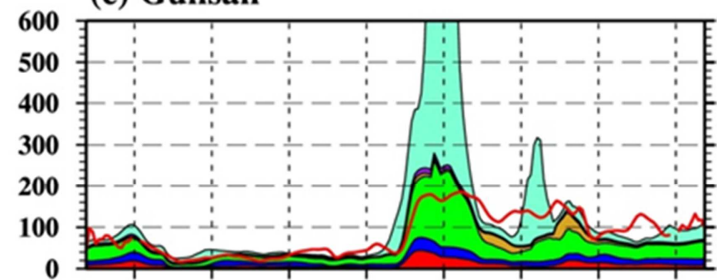

(f) Gwangju

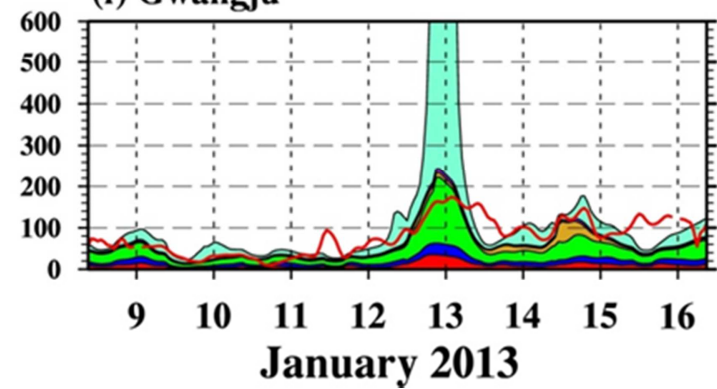
政 15

Fig. 3. Time series of hourly mean observed (red line) and modeled (shaded colors for various aerosols) $\mathrm{PM}_{10}$ concentration $\left(\mu \mathrm{g} \mathrm{m}^{-3}\right.$ ) at (a) Baengnyeongdo, (b) Heuksando, (c) Gosan, (d) Seoul, (e) Gunsan and (f) Gwangju in South Korea for the period of 09:00 LST 8 to 09:00 LST 16 January 2010. Model simulated concentrations of the water droplet (Water - Sea salt and Secondary organic aerosol (OTHER $\square$ ), Asian dust ( $\square$ ), Secondary Inorganic Aerosol (SIA $\square$ ), Black Carbon and Organic Carbon (BC and OC $\boldsymbol{~ ) \text { , Anthropogenically emitted } \mathrm { PM } _ { 1 0 } ( \text { Unspecified } \mathrm { PM } _ { 1 0 }}$ ) are indicated. 
(a) Asian Dust $\left(\mu \mathrm{g} / \mathrm{m}^{3}\right)$

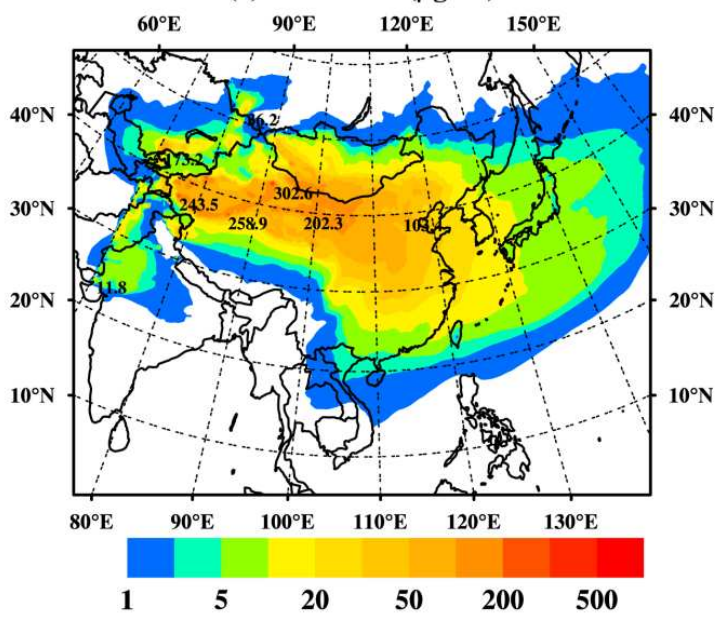

(b) Anthropogenic aerosol $\left(\mu \mathrm{g} / \mathrm{m}^{3}\right)$

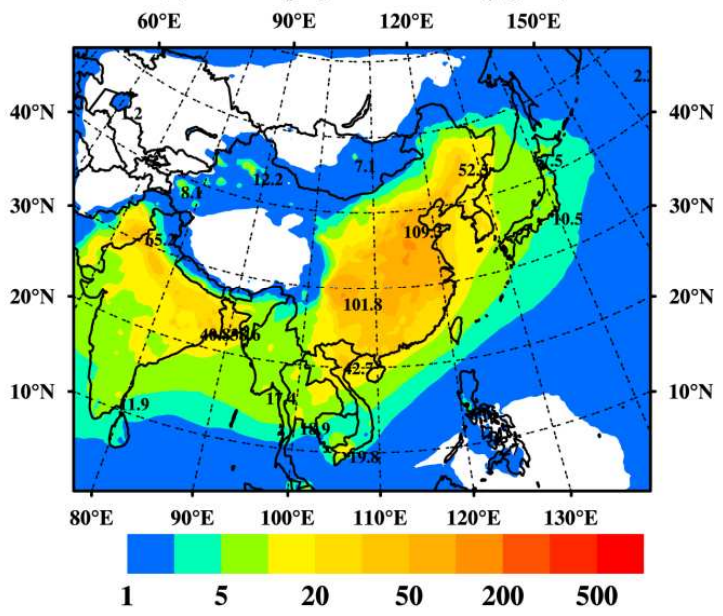

(c) Total Aerosol $\left(\mu \mathrm{g} / \mathrm{m}^{3}\right)$

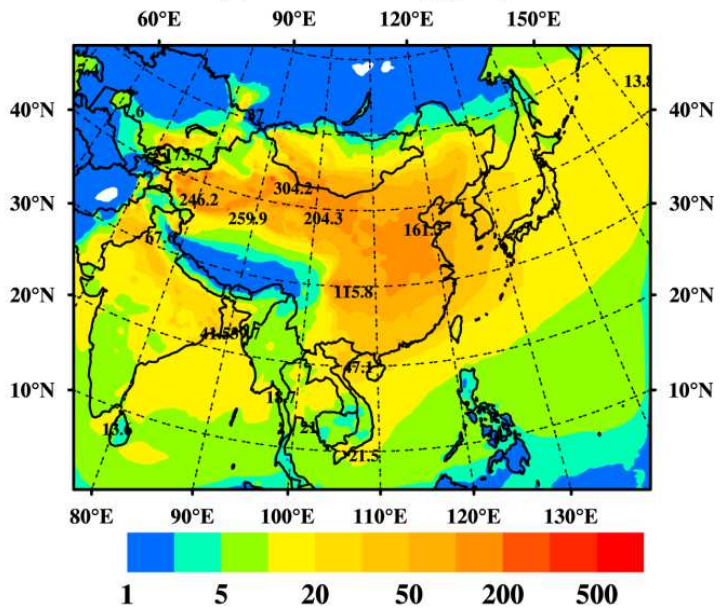

2 Fig. 4. Spatial distributions of annual mean surface concentration $\left(\mu \mathrm{g} \mathrm{m}^{-3}\right)$ of (a) Asian dust aerosol $3\left(\mathrm{PM}_{10}\right)$, (b) anthropogenic aerosols (SIA, SOA, BC, OC, anthropogenic $\mathrm{PM}_{10}$ ) and (c) total aerosol for 4 the year 2010. Numbers indicate the local maximum values. 
(a) Column Integrated Asian Dust aerosol ( $\mathrm{mg} \mathrm{m}^{-2}$ )

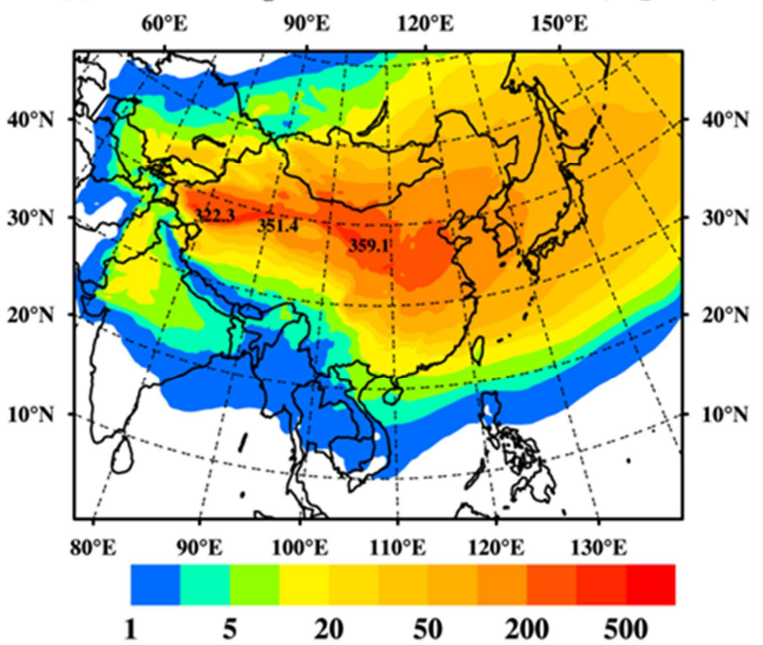

(b) Column Integrated Anth. aerosol ( $\mathrm{mg} \mathrm{m}^{-2}$ )

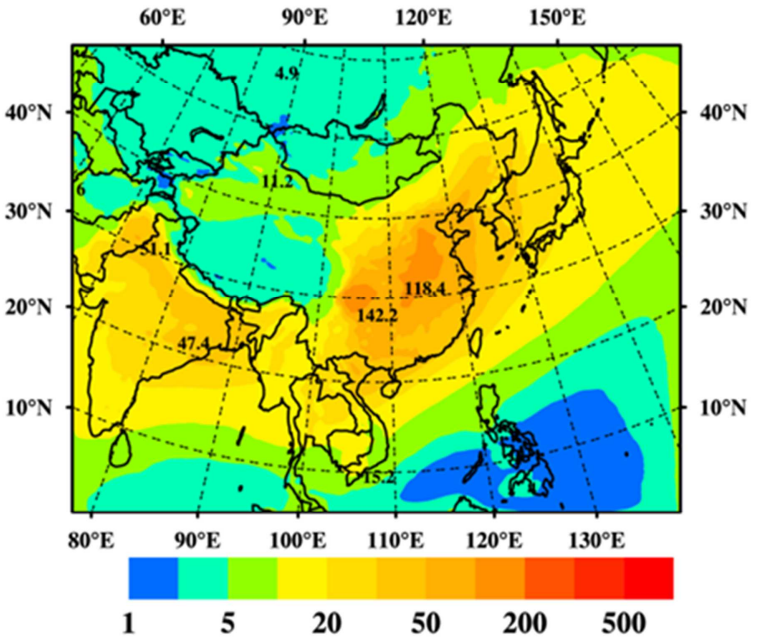

(c) Column Integrated Total aerosol $\left(\mathrm{mg} \mathrm{m}^{-2}\right)$

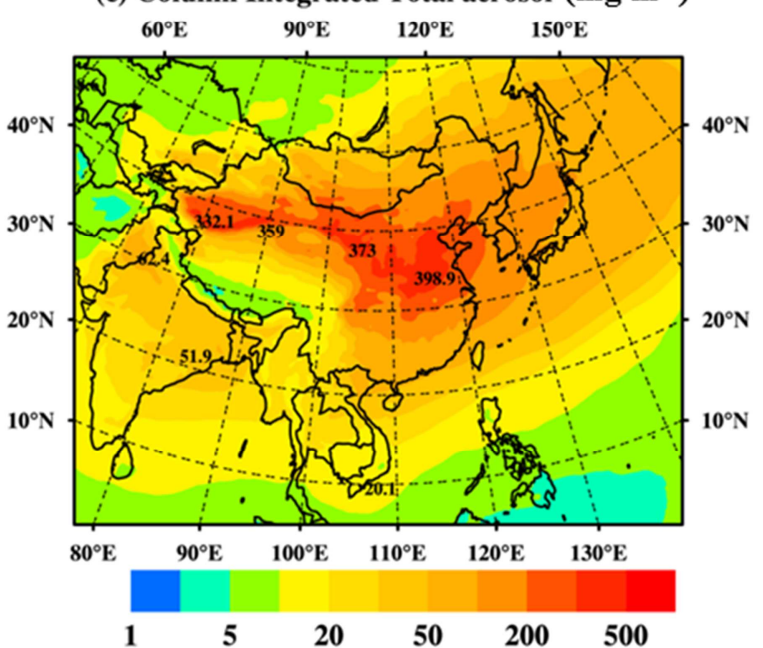

2 Fig. 5. The same as in Fig. 4 except for the column integrated $\mathrm{PM}_{10}$ concentration $\left(\mathrm{mg} \mathrm{m}^{-2}\right)$. 
(a) Total deposition of dust (ton/ $\mathrm{km}^{2}$ )

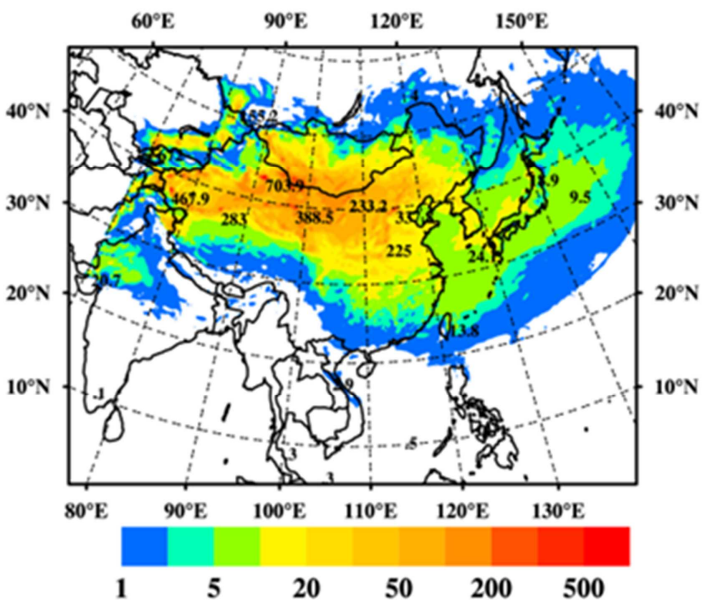

(b) Dry deposition of dust (ton $/ \mathrm{km}^{2}$ )

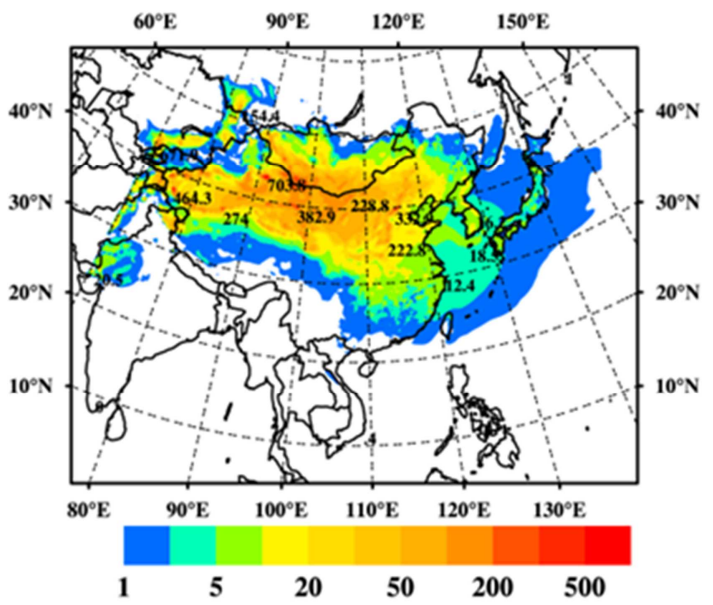

(c) Wet deposition of dust (ton $/ \mathrm{km}^{2}$ )

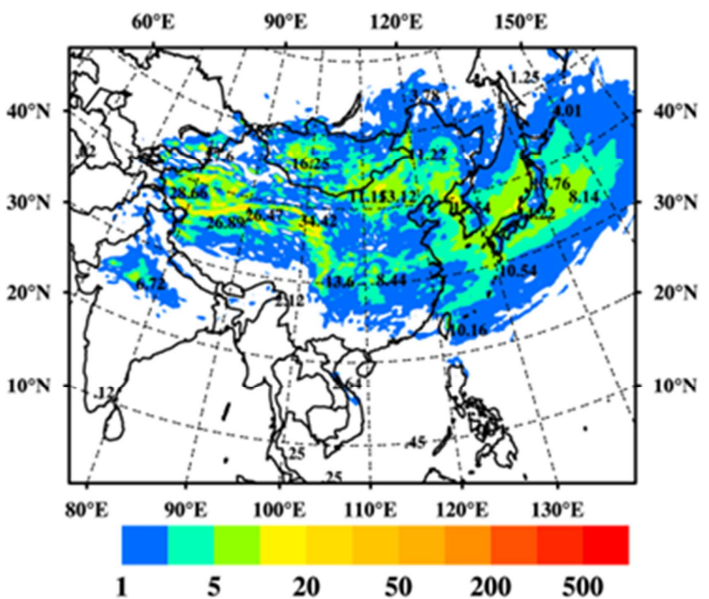

$371.8 \mathrm{Tg}$

$305.3 \mathrm{Tg}$

$66.5 \mathrm{Tg}$

2 Fig. 6. Spatial distributions of annual (a) total deposition (Dry + Wet $\mathrm{t} \mathrm{km}^{-2}$ ), (b) dry deposition $\left(\mathrm{t} \mathrm{km}^{-2}\right)$

3 and (c) wet deposition $\left(\mathrm{t} \mathrm{km}^{-2}\right)$ of the Asian dust aerosol in 2010. 
(a) Total deposition of Anth. aerosol (ton $/ \mathrm{km}^{2}$ )

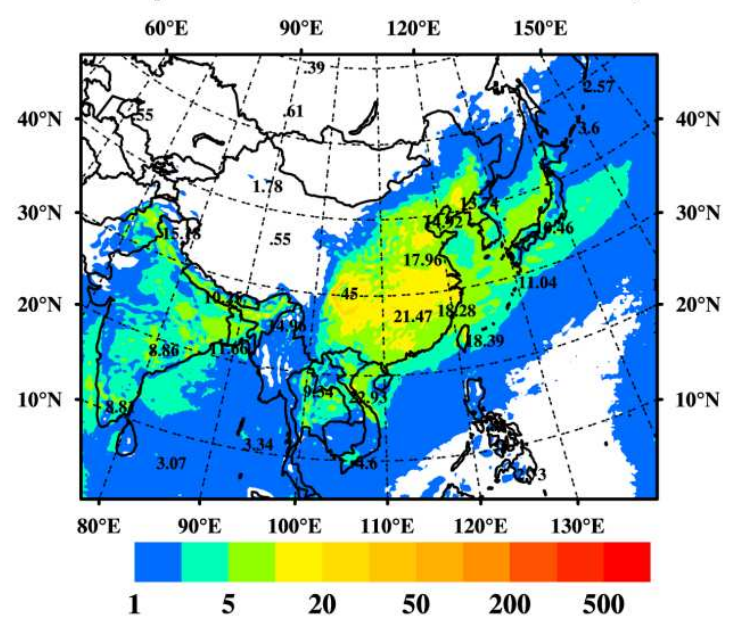

$113.4 \mathrm{Tg}$

(b) Dry deposition of Anth. aerosol (ton $/ \mathrm{km}^{2}$ )

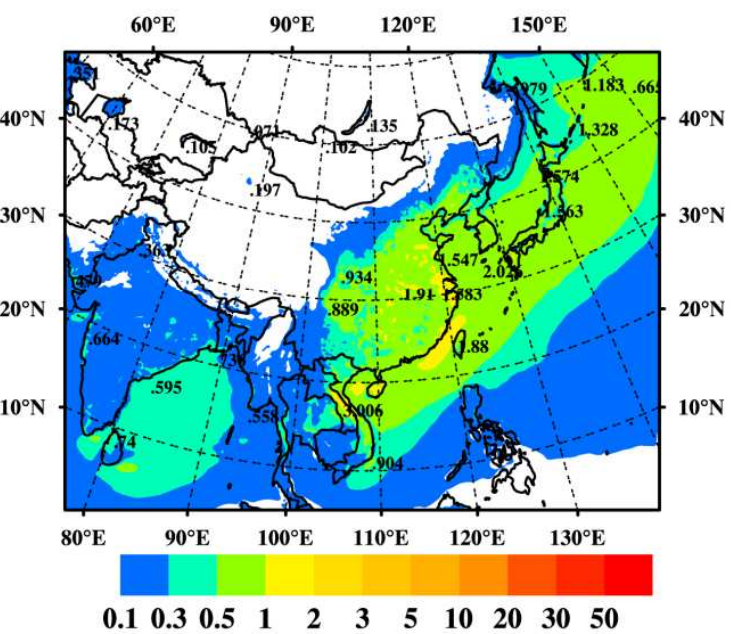

$13.3 \mathrm{Tg}$

(c) Wet deposition of Anth. aerosol (ton $/ \mathrm{km}^{2}$ )

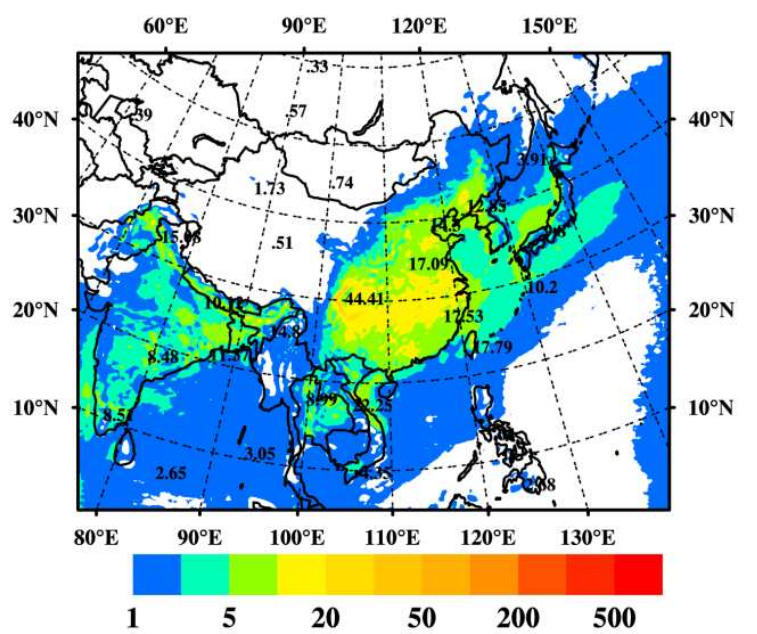

$100.1 \mathrm{Tg}$

2 Fig. 7. The same as in Fig. 6 but for the anthropogenic aerosol. 


\section{(a) Total deposition (ton $/ \mathrm{km}^{2}$ )}

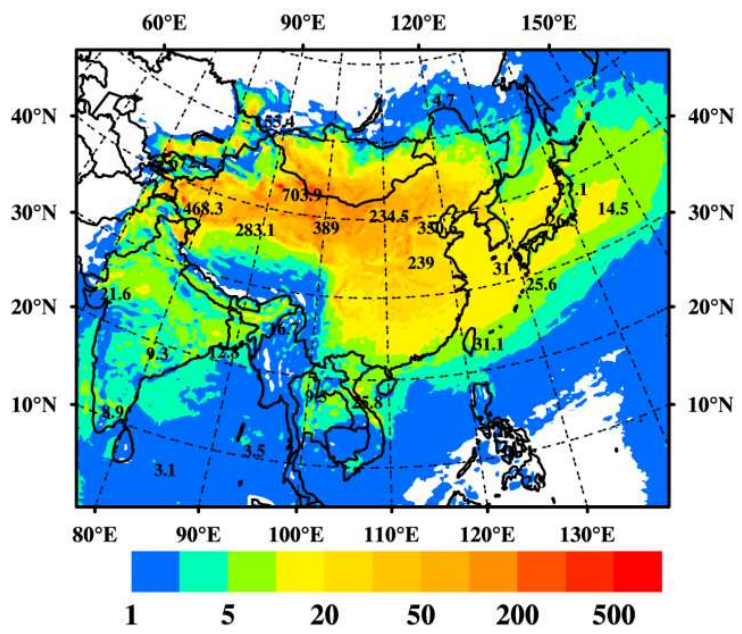

$485.2 \mathrm{Tg}$

(b) Total Dry deposition (ton $/ \mathrm{km}^{2}$ )

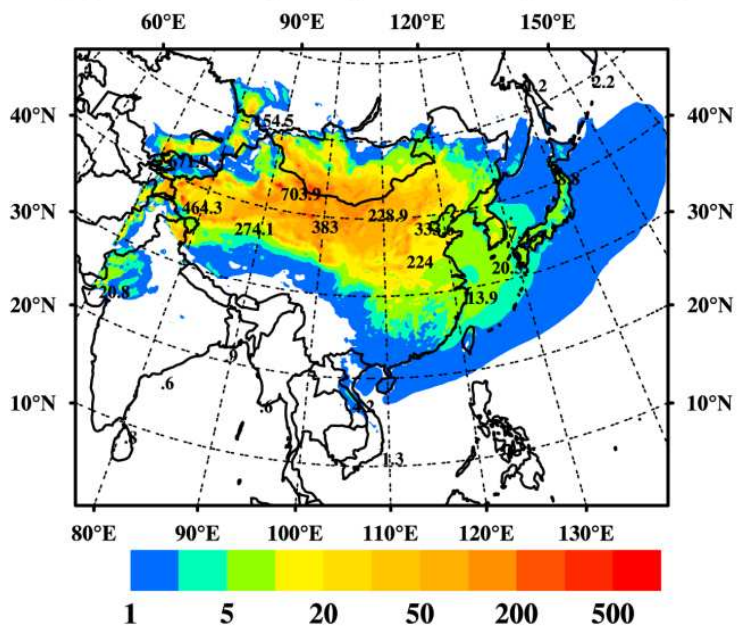

$318.6 \mathrm{Tg}$

(c) Total Wet deposition (ton $/ \mathrm{km}^{2}$ )

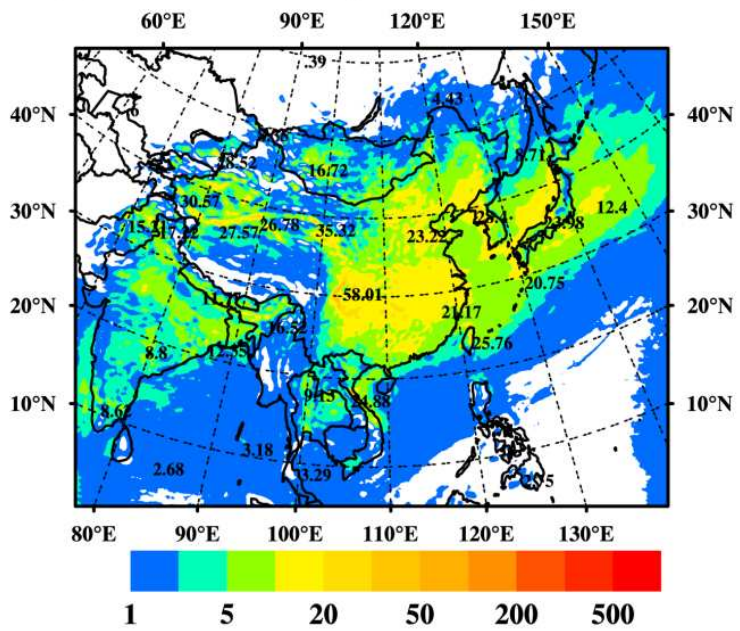

$166.6 \mathrm{Tg}$

2 Fig. 8. The same as in Fig. 6 but for the total aerosol (Asian dust + anthropogenic aerosol). 
1 Table 1. Quantitative performance statistics for near surface aerosol $\left(\mathrm{PM}_{10}\right)$ concentration simulations 2 with AMS in South Korea. Mean (o) and Mean (m) represent the observed modeled mean

3 concentration, respectively; SD (o) and SD (m) the ovserved and modeled standard devitaion $\left(\mu \mathrm{g} \mathrm{m}^{-3}\right)$,

4 respectiviely; MNB the mean normalized BIAS (\%); CORR COEF the correlation coefficeient; RMSE

5 the root mean square error $\left(\mu \mathrm{g} \mathrm{m}^{-3}\right)$; NMSE the normalized mean square error; FAC2 the fraction of

6 simulations within a factor of 2 of observations.

\begin{tabular}{|c|c|c|c|c|c|c|c|c|c|c|}
\hline Mon & $\begin{array}{c}\text { Mean }(\mathrm{o}) \\
\left(\mu \mathrm{g} \mathrm{m}^{-3}\right)\end{array}$ & $\begin{array}{c}\text { Mean }(\mathrm{m}) \\
\left(\mu \mathrm{g} \mathrm{m}^{-3}\right)\end{array}$ & $\begin{array}{c}\mathrm{SD}(\mathrm{o}) \\
\left(\mu \mathrm{g} \mathrm{m}^{-3}\right)\end{array}$ & $\begin{array}{c}\mathrm{SD}(\mathrm{m}) \\
\left(\mu \mathrm{g} \mathrm{m}^{-3}\right)\end{array}$ & $\begin{array}{c}\text { BIAS } \\
\left(\mu \mathrm{g} \mathrm{m}^{-3}\right)\end{array}$ & $\begin{array}{c}\text { MNB } \\
(\%)\end{array}$ & $\begin{array}{c}\text { CORR } \\
\text { COEF }\end{array}$ & $\begin{array}{c}\text { RMSE } \\
\left(\mu \mathrm{g} \mathrm{m}^{-3}\right)\end{array}$ & $\begin{array}{c}\text { NMSE } \\
(\%)\end{array}$ & $\begin{array}{c}\text { FAC2 } \\
(\%)\end{array}$ \\
\hline 1 & 41.5 & 44.8 & 25.0 & 36.2 & 3.1 & 7 & 0.62 & 11.6 & 7.2 & 71 \\
\hline 2 & 35.7 & 39.6 & 22.3 & 34.0 & 3.0 & 8 & 0.60 & 10.4 & 7.8 & 67 \\
\hline 3 & 54.5 & 58.1 & 67.0 & 66.4 & 3.6 & 7 & 0.65 & 3.6 & 0.4 & 63 \\
\hline 4 & 39.6 & 53.6 & 22.7 & 50.2 & 14.5 & 36 & 0.48 & 30.6 & 44 & 65 \\
\hline 5 & 45.5 & 50.1 & 34.7 & 45.7 & 4.9 & 11 & 0.72 & 12.0 & 6.3 & 64 \\
\hline 6 & 28.9 & 25.3 & 21.9 & 15.6 & -3.5 & -12 & 0.44 & 6.9 & 6.5 & 58 \\
\hline 7 & 23.9 & 15.8 & 17.2 & 12.2 & -8.0 & -34 & 0.55 & 9.4 & 23.5 & 57 \\
\hline 8 & 25.9 & 25.3 & 20.3 & 19.9 & -0.6 & -2 & 0.50 & 0.7 & 0.1 & 47 \\
\hline 9 & 24.9 & 21.1 & 18.1 & 16.4 & -3.8 & -15 & 0.50 & 4.1 & 3.2 & 55 \\
\hline 10 & 34.8 & 28.0 & 18.8 & 20.5 & -6.8 & -19 & 0.51 & 7.0 & 5.0 & 62 \\
\hline 11 & 62.8 & 58.2 & 61.4 & 58.4 & -4.6 & -7 & 0.53 & 5.5 & 0.8 & 68 \\
\hline 12 & 53.6 & 57.1 & 44.6 & 51.7 & 3.8 & 7 & 0.65 & 8.0 & 2.1 & 67 \\
\hline $\begin{array}{c}\text { Annual } \\
\text { mean }\end{array}$ & 39.3 & 39.7 & 31.2 & 35.6 & 0.5 & 0.3 & 0.56 & 9.2 & 5.5 & 62 \\
\hline
\end{tabular}

7

8

9

10

11

12 
1 Table 2. Quantitative performance statistics for near surface aerosol concentration simulations for the 2 year 2010 at four monitoring sites in China.

\begin{tabular}{|c|c|c|c|c|c|c|c|c|c|}
\hline SITE & $\begin{array}{c}\text { Annual } \\
\text { mean }(\mathrm{o}) \\
\left(\mu \mathrm{g} \mathrm{m}^{-3}\right)\end{array}$ & $\begin{array}{c}\text { Annual } \\
\text { mean (m) } \\
\left(\mu \mathrm{g} \mathrm{m}^{-3}\right)\end{array}$ & $\begin{array}{c}\mathrm{SD}(\mathrm{o}) \\
\left(\mu \mathrm{g} \mathrm{m}^{-3}\right)\end{array}$ & $\begin{array}{c}\mathrm{SD}(\mathrm{m}) \\
\left(\mu \mathrm{g} \mathrm{m}^{-3}\right)\end{array}$ & $\begin{array}{c}\text { BIAS } \\
\left(\mu \mathrm{g} \mathrm{m}^{-3}\right)\end{array}$ & $\begin{array}{c}\text { MNB } \\
(\%)\end{array}$ & $\begin{array}{c}\text { RMSE } \\
\left(\mu \mathrm{g} \mathrm{m}^{-3}\right)\end{array}$ & $\begin{array}{c}\text { NMSE } \\
(\%)\end{array}$ & $\begin{array}{c}\text { CORR } \\
\text { COEF } \\
\left(\mu \mathrm{g} \mathrm{m}^{-3}\right)\end{array}$ \\
\hline Humin & 177.8 & 170.5 & 90.5 & 82.0 & -7.3 & -9.5 & 11.3 & 0.5 & 0.56 \\
\hline Jurihe & 158.5 & 137.7 & 257.0 & 231.0 & -21.1 & -20.0 & 33.4 & 5.1 & 0.59 \\
\hline Yushe & 72.9 & 92.4 & 102.5 & 91.1 & 20.0 & 20.7 & 23.0 & 7.8 & 0.49 \\
\hline Dlian & 67.2 & 58.5 & 55.8 & 60.1 & -11.7 & -17.0 & 12.5 & 4.0 & 0.52 \\
\hline
\end{tabular}

3

4

5

6

7

8

9

10

11

12

13

14

15

16

17

18

19

20

21

22 
1 Table 3. Modeled and observed annual total wet deposition of secondary inorganic aerosol (SIA;

2 sulfate, nitrate and ammonium) at several sites in the EANET in 2010.

\begin{tabular}{|c|c|c|c|c|}
\hline \multirow{2}{*}{ SITE } & \multicolumn{2}{|c|}{ Location } & \multirow{2}{*}{$\begin{array}{c}\text { Modeled Wet Deposition } \\
\text { of SIA }\left(\mathrm{kg} \mathrm{km}^{-2}\right)\end{array}$} & $\begin{array}{c}\text { Observed Wet Deposition } \\
\text { of SIA }\left(\mathrm{kg} \mathrm{km}^{-2}\right)\end{array}$ \\
\cline { 2 - 3 } & Latitude (N) & Longitude (E) & & $4.503 \times 10^{3}$ \\
\hline Gosan & 33.28 & 126.17 & $4.129 \times 10^{3}$ & $8.967 \times 10^{3}$ \\
\hline Ganghwa & 37.71 & 126.44 & $5.707 \times 10^{3}$ & $4.138 \times 10^{3}$ \\
\hline Rishiri & 45.12 & 141.21 & $2.378 \times 10^{3}$ & $6.527 \times 10^{3}$ \\
\hline Sado-Seki & 38.25 & 138.40 & $4.068 \times 10^{3}$ & $9.063 \times 10^{3}$ \\
\hline Oki & 36.29 & 133.19 & $7.263 \times 10^{3}$ & \\
\hline
\end{tabular}

3

4

5

6 